\title{
TU/e EN⿴HONE

\section{Resistive intrinsic ZnO films deposited by ultrafast spatial ALD for PV applications}

\section{Citation for published version (APA):}

Nandakumar, N., Dielissen, S. A. F., Garcia-Alonso Garcia, D., Liu, Z., Görtzen, R., Kessels, W. M. M., Aberle, A. G., \& Hoex, B. (2015). Resistive intrinsic ZnO films deposited by ultrafast spatial ALD for PV applications. IEEE Journal of Photovoltaics, 5(5), 1462-1469. https://doi.org/10.1109/JPHOTOV.2015.2438644

\section{Document license: \\ TAVERNE}

DOI:

10.1109/JPHOTOV.2015.2438644

Document status and date:

Published: 01/01/2015

\section{Document Version:}

Publisher's PDF, also known as Version of Record (includes final page, issue and volume numbers)

\section{Please check the document version of this publication:}

- A submitted manuscript is the version of the article upon submission and before peer-review. There can be important differences between the submitted version and the official published version of record. People interested in the research are advised to contact the author for the final version of the publication, or visit the $\mathrm{DOI}$ to the publisher's website.

- The final author version and the galley proof are versions of the publication after peer review.

- The final published version features the final layout of the paper including the volume, issue and page numbers.

Link to publication

\section{General rights}

Copyright and moral rights for the publications made accessible in the public portal are retained by the authors and/or other copyright owners and it is a condition of accessing publications that users recognise and abide by the legal requirements associated with these rights.

- Users may download and print one copy of any publication from the public portal for the purpose of private study or research.

- You may not further distribute the material or use it for any profit-making activity or commercial gain

- You may freely distribute the URL identifying the publication in the public portal.

If the publication is distributed under the terms of Article 25fa of the Dutch Copyright Act, indicated by the "Taverne" license above, please follow below link for the End User Agreement:

www.tue.nl/taverne

Take down policy

If you believe that this document breaches copyright please contact us at:

openaccess@tue.nl

providing details and we will investigate your claim. 


\title{
Resistive Intrinsic ZnO Films Deposited by Ultrafast Spatial ALD for PV Applications
}

\author{
Naomi Nandakumar, Bas Dielissen, Diana Garcia-Alonso, Zhe Liu, Roger Görtzen, \\ Wilhelmus M. M. (Erwin) Kessels, Armin G. Aberle, and Bram Hoex
}

\begin{abstract}
Spatial atomic layer deposition (ALD) of intrinsic zinc oxide $(i-\mathrm{ZnO})$ films is scaled up from the laboratory to the industrial level, and the film properties are investigated in detail. A high growth rate of $35 \mathrm{~nm} / \mathrm{min}$ is achieved. The deposited films are transparent and have an unusually high resistivity of about $100 \Omega \cdot \mathrm{cm}$. This is attributed to the extremely short precursor exposure and purge duration of spatial ALD $(\sim 8 \mathrm{~ms})$, as compared with temporal ALD ( 1-10 s). The growth of highly crystalline and nearly stoichiometric $i$-ZnO films is achieved. This makes these $i$ - $\mathrm{ZnO}$ layers ideal for applications as insulating window layers in $\mathrm{Cu}(\mathrm{In}, \mathrm{Ga}) \mathrm{Se}_{2}$ solar cells.
\end{abstract}

Index Terms-Atomic layer deposition (ALD), $\mathrm{Cu}(\mathrm{In}, \mathrm{Ga}) \mathrm{Se}_{2}$ (CIGS), photovoltaics, solar cells, spatial, thin films, transparent conductive oxides, zinc oxide.

\section{INTRODUCTION}

I NTRINSIC zinc oxide ( $i$ - $\mathrm{ZnO})$ is a widebandgap semiconductor with a variety of useful properties that have made it a material of increasing attention in numerous fields of research [1]. The high transparency of $\mathrm{ZnO}$ in the visible wavelength range combined with its tunable electrical conductivity enables its use in devices such as transparent electronics [2], gas sensors [3], and solar cells [4]. $\mathrm{ZnO}$ has a direct bandgap of $3.37 \mathrm{eV}$ at room temperature [5]. Thin films of $\mathrm{ZnO}$ are used in the photovoltaic (PV) industry in the undoped, as well as doped form, for example, in record-efficiency $\mathrm{Cu}(\mathrm{In}, \mathrm{Ga}) \mathrm{Se}_{2}$ (CIGS) thin-film solar cells and in silicon heterojunction solar cells [6]-[8]. In a standard CIGS configuration, a $\mathrm{ZnO}$ bilayer is used, consisting of a resistive $i-\mathrm{ZnO}$ layer capped with a doped $\mathrm{ZnO}$ layer. This

Manuscript received March 6, 2015; revised May 7, 2015; accepted May 21, 2015. Date of publication June 26, 2015; date of current version August 18, 2015. This work was supported by the National Research Foundation, Prime Minister's Office, Singapore, under its Energy Innovation Research Program (EIRP Award NRF2011EWT-CERP001-018). The Solar Energy Research Institute of Singapore is sponsored by the National University of Singapore and Singapore's National Research Foundation through the Singapore Economic Development Board.

N. Nandakumar, Z. Liu, and A. G. Aberle are with the Solar Energy Research Institute of Singapore, Singapore 117574 (e-mail: naomi. nandakumar@nus.edu.sg; zhe.liu@nus.edu.sg; armin.aberle@nus.edu.sg).

B. Dielissen and R. Görtzen are with SoLayTec B.V., Eindhoven 5652 AM, The Netherlands (e-mail: bas.dielissen@solaytec.com; roger.gortzen@ solaytec.com).

D. Garcia-Alonso and W. M. M. Kessels are with the Department of Applied Physics, Eindhoven University of Technology, Eindhoven 5600 MB, The Netherlands (e-mail: d.garcia-alonso@tue.nl; w.m.m.kessels@tue.nl).

B. Hoex was with the Solar Energy Research Institute of Singapore, Singapore 117574 . He is now with the School of Photovoltaic and Renewable Energy Engineering, University of New South Wales, Sydney, N.S.W. 2052, Australia (e-mail: b.hoex@unsw.edu.au).

Color versions of one or more of the figures in this paper are available online at http://ieeexplore.ieee.org.

Digital Object Identifier 10.1109/JPHOTOV.2015.2438644 thin $i$-ZnO layer has been an integral component of CIGS solar cells over the years, because it has been consistently shown to improve reproducibility and production yield for this type of solar cell [4]. This improvement is attributed to the role of resistive $i-\mathrm{ZnO}$ in preventing the formation of shunts between the highly doped $\mathrm{ZnO}$ front contact and the molybdenum rear contact through pin holes and crevices in the inhomogeneous absorber layer [9]. The presence of the resistive $i$ - $\mathrm{ZnO}$ layer results in higher resistive losses and increased carrier recombination at the buffer/absorber interface due to an increased separation between the Fermi level and the conduction band of the absorber [10]. However, numerical modeling and experimental studies have shown that this high series resistance provided by the $i$-ZnO layer prevents spatial electrical inhomogeneities (e.g., low-performance areas of locally enhanced recombination) from dominating the open-circuit voltage of the entire device [10]-[12]. This explains the high solar cell efficiencies obtained even when $\sim 100-\mathrm{nm} i$-ZnO layers are used [13].

The preferred deposition technique for $i$-ZnO films in the $\mathrm{PV}$ industry is direct current and reactive sputtering from ceramic and metal targets, respectively [4]. However, sputtering of $i$-ZnO films has been shown to cause significant surface damage to the underlying absorber layer due to highly energetic ions and other plasma-induced effects [14], [15]. Consequently, there is a need for a low-damage technique for the deposition of the $i$-ZnO layer.

Atomic layer deposition (ALD) is one such deposition technique. Due to its self-limiting chemical reactions at low substrate temperatures, uniform growth and precise thickness control can be achieved in addition to low surface damage. Conventional (also known as temporal) ALD has been a less popular choice in the PV industry due to its low deposition rate of $<2 \mathrm{~nm} / \mathrm{min}$. One way to increase throughput is by using batch reactors. Alternatively, the recent development of the spatial ALD technique achieves high growth rates by separating the gaseous precursors in space rather than in time [16]. A moving substrate is sequentially exposed to each precursor as illustrated in Fig. 1, removing the requirement for separate pumping cycles between each exposure. This combines the advantages of conventional ALD (i.e., the growth of uniform, pinhole-free, and highly conformal films on large-area substrates) with high deposition rates, making it an attractive option for the PV industry.

In 2011, Illiberi et al. demonstrated the deposition of $i-\mathrm{ZnO}$ films by spatial ALD on a prototype lab-scale system consisting of a circular reactor head with inlets for each precursor [17]. The substrate was placed on a circular table that rotated underneath the reactor head. In the present work, the deposition 


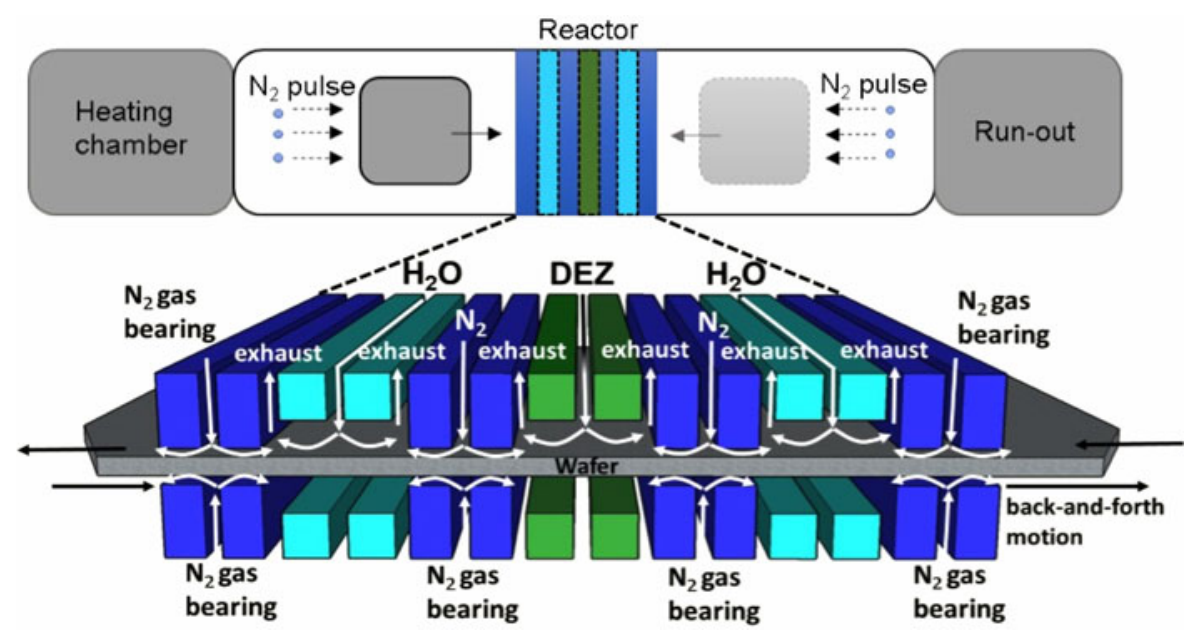

Fig. 1. Schematic illustration of the working principle of spatial ALD. The gaseous precursors (DEZ and $\mathrm{H}_{2} \mathrm{O}$ ) are separated in space rather than in time, as in the case of temporal ALD. The substrate is moved back and forth by $\mathrm{N}_{2}$ pulses on either side of the reactor. Each pass results in one ALD cycle.

of $i$-ZnO has been successfully scaled up using a commercial spatial ALD system currently used in the PV industry. Highly uniform $i$ - $\mathrm{ZnO}$ films with precisely controlled thickness, high transparency ( $>90 \%$ in the visible wavelength range), and exceptionally high resistivity $(\sim 100 \Omega \cdot \mathrm{cm})$ were deposited at growth rates up to $\sim 35 \mathrm{~nm} / \mathrm{min}$ at low deposition temperatures $\left(<250{ }^{\circ} \mathrm{C}\right)$ and at atmospheric pressure. In earlier work, we showed that ultrafast ALD can be used to deposit uniform $i$ - $\mathrm{ZnO}$ films at low temperatures and with low precursor consumption [18]. In this paper, we build on that work by investigating the properties of the $i$ - $\mathrm{ZnO}$ films in detail and furthermore studying the effect of the short exposure and purge durations of spatial ALD on its electrical and structural properties.

\section{EXPERIMENTAL DETAILS}

$i$-ZnO films were deposited using SoLayTec's InPassion LAB spatial ALD system. A schematic of the system is shown in Fig. 1. Diethyl zinc (DEZn SSG, AkzoNobel) and deionized water vapor $\left(\mathrm{H}_{2} \mathrm{O}\right)$ were used as the ALD precursors. Nitrogen $\left(\mathrm{N}_{2}>99.999 \%\right.$, Air Liquide) was used as the carrier gas for both precursors and also as a gaseous separation curtain for the precursor gases in the reactor. All precursors were transported to the reactor through heated lines to prevent condensation. Both DEZ and $\mathrm{H}_{2} \mathrm{O}$ were further heated to the deposition temperature in a heat exchanger before being injected into the reactor through slits. Each slit is flanked by exhaust channels that carry away excess gas on each side, with two adjacent slits sharing one exhaust as shown in Fig. 1. During deposition, the sample is supported by $\mathrm{N}_{2}$ gas bearings from the top and bottom which keep the sample floating in the reactor throughout deposition. The sample is also moved steadily back and forth inside the reactor at a fixed wafer speed, using pulses of $\mathrm{N}_{2}$ at both ends of the reactor. During each pass, the wafer is exposed to one DEZ slit and two $\mathrm{H}_{2} \mathrm{O}$ slits for each ALD cycle. Hence, in such a spatial ALD system, the pulse (exposure to DEZ and $\mathrm{H}_{2} \mathrm{O}$ ) and purge durations are fixed for a certain wafer speed. Unlike in temporal ALD, here, the pulse for each reactant and the purge time in between pulses cannot be independently varied.
Typical DEZ-based $i$-ZnO deposition temperatures for ALD range from 100 to $250{ }^{\circ} \mathrm{C}$ [19]. In the present work, this same temperature range was used for the reactor and precursor gases. Prior to the ALD process, the wafer is heated from room temperature to the deposition temperature in the run-in heating chamber and in an inert $\mathrm{N}_{2}$ atmosphere.

$i$ - $\mathrm{ZnO}$ films were deposited on pseudosquare $125 \mathrm{~mm} \times$ $125 \mathrm{~mm}$ p-type Czochralski $c$-Si substrates with a $\left(\begin{array}{llll}1 & 0 & 0\end{array}\right)$ crystal orientation. However, $156 \mathrm{~mm} \times 156 \mathrm{~mm}$ wafers can also be easily processed in the same system. All substrates were cleaned using a standard Radio Corporation of America clean [20], followed by a dip in $1 \%$ hydrofluoric acid with a final rinse in water before drying. In order to enable spectroscopic ellipsometry (SE) measurements, the films were deposited on single-side polished $c$-Si substrates. The SE substrates were prepared by chemical-mechanical polishing, resulting in a surface roughness of less than $5 \AA$. For electrical measurements, the films were deposited on as-procured polished $c$-Si samples with a 150-nm insulating layer of thermally grown $\mathrm{SiO}_{2}$.

The thickness and optical properties of all films were measured using a spectroscopic ellipsometer (J. A. Woollam, M2000) in the visible and near-infrared (NIR) wavelength range from 250 to $1700 \mathrm{~nm}$ at $65^{\circ}, 70^{\circ}$, and $75^{\circ}$. The pSemi-M0 oscillator model was used to fit the measured SE data [21]. The refractive indexes $(n)$ and extinction coefficients $(k)$ obtained from the ellipsometry measurements were used to simulate transmission and absorption spectra of the $i-\mathrm{ZnO}$ films for a typical CIGS solar cell structure, using the transfer matrix method in Mathematica. The $n$ and $k$ values of magnesium fluoride $\left(\mathrm{MgF}_{2}\right)$, cadmium selenide (CdS), and CIGS were obtained from the literature [22]-[24], while those of Al-doped $\mathrm{ZnO}(\mathrm{AZO})$ were measured in-house. Electrical properties were measured using a four-point probe mapping system (4PP, Advanced Instrument Technology, CMT-SR2000N-PV). The structural characterization of the films was done by scanning electron microscopy (SEM, Carl Zeiss, Auriga) and X-ray diffraction (XRD, PANalytical, X'Pert Pro MRD). X-ray photoelectron spectroscopy (XPS, Thermo Scientific K-Alpha, KA1066) with monochromatic $\mathrm{Al} \mathrm{K}_{\alpha} \mathrm{X}$-ray radiation $(h v=1486.6 \mathrm{eV}$, spot 
size $=400 \mu \mathrm{m})$ was used to assess the chemical composition of the films. All samples were corrected for sample charging with a flood gun. The sensitivity factors used for quantification were calibrated with Rutherford backscattering spectrometry as reported elsewhere [25]. For depth profiling, an Ar gun was applied to sputter the $i-\mathrm{ZnO}$ films.

\section{RESULTS AND DISCUSSION}

\section{A. Film Growth Characteristics}

DEZ and $\mathrm{H}_{2} \mathrm{O}$ used for ALD of $i-\mathrm{ZnO}$ react as follows:

$$
s-\mathrm{Zn}\left(\mathrm{CH}_{2} \mathrm{CH}_{3}\right)(\mathrm{g})+\mathrm{H}_{2} \mathrm{O}(\mathrm{g}) \rightarrow s-\mathrm{ZnO}(\mathrm{s})+2 \mathrm{C}_{2} \mathrm{H}_{6}(\mathrm{~g})
$$

where $s$ - denotes surface species. The above reaction can be split further into two self-limiting half reactions that occur on exposure to each precursor [26]:

$$
s-\mathrm{Zn}-\mathrm{OH}+\mathrm{Zn}\left(\mathrm{CH}_{2} \mathrm{CH}_{3}\right)_{2} \rightarrow s-\mathrm{Zn}-\mathrm{O}-\mathrm{Zn}\left(\mathrm{CH}_{2} \mathrm{CH}_{3}\right)+\mathrm{C}_{2} \mathrm{H}_{6}
$$

$$
s-\mathrm{Zn}-\left(\mathrm{CH}_{2} \mathrm{CH}_{3}\right)+\mathrm{H}_{2} \mathrm{O} \rightarrow \mathrm{s}-\mathrm{Zn}-\mathrm{OH}+\mathrm{C}_{2} \mathrm{H}_{6} \text {. }
$$

The reaction of DEZ with $\mathrm{H}_{2} \mathrm{O}$ is exothermic and can be used to deposit $i$ - $\mathrm{ZnO}$ thin films at substrate temperatures much lower than are required for other processes with different precursors. In Fig. 2(a), the relation between film thickness and the number of ALD cycles is shown for an $i$-ZnO film deposited at a substrate temperature of $225{ }^{\circ} \mathrm{C}$. It can be seen that the film thickness increases linearly with the number of ALD cycles, as is expected for an ALD process. The linear fit of the data in Fig. 2 indicates a short nucleation delay, which is quite typical for ALD of $i-\mathrm{ZnO}$. The increase in thickness was linear after this initial lag. From the slope of the line, the growth per cycle (GPC) was found to be $\sim 0.19 \mathrm{~nm} /$ cycle for a DEZ partial pressure of $2 \mathrm{mbar}$, an $\mathrm{H}_{2} \mathrm{O}$ partial pressure of $65 \mathrm{mbar}$, and a pulse and purge time of $\sim 8 \mathrm{~ms}$ each. This GPC value is found to correlate well with the interplanar distances in a hexagonal unit cell of $i-\mathrm{ZnO}$, which range from $0.25 \mathrm{~nm}$ for the $\left(\begin{array}{lll}1 & 0 & 1\end{array}\right)$ planes to 0.26 and $0.28 \mathrm{~nm}$ for the $\left(\begin{array}{lll}0 & 0 & 2\end{array}\right)$ and $\left(\begin{array}{lll}1 & 0 & 0\end{array}\right)$ planes, respectively, indicating that the $i$ - ZnO GPC is very close to ideal monolayer growth values [27]. This observation corresponds well to existing reports of $i$-ZnO GPC values by temporal ALD as well as spatial ALD in this deposition temperature range [5], [17]. Each cycle takes $\sim 0.3 \mathrm{~s}$, resulting in a deposition rate of $\sim 35 \mathrm{~nm} / \mathrm{min}$ for a GPC of $0.19 \mathrm{~nm} /$ cycle.

The reported optimum ALD temperature window and the temperature at which growth saturation for $i$ - $\mathrm{ZnO}$ is achieved varies largely [5]. It is likely that reactor design and other factors such as the position of temperature sensors, reactor shape, and reactor size influence the values reported for ALD temperature windows. A temperature range from 100 to $250{ }^{\circ} \mathrm{C}$ was chosen in this study. Fig. 2(b) illustrates the GPC of $i$-ZnO films as a function of the substrate temperature. Maximum GPC for $i$ - $\mathrm{ZnO}$ growth was achieved at $200{ }^{\circ} \mathrm{C}$, after which the GPC remained constant at $\sim 0.19 \mathrm{~nm} /$ cycle. The DEZ and $\mathrm{H}_{2} \mathrm{O}$ partial pressures were optimized in previous work to identify the

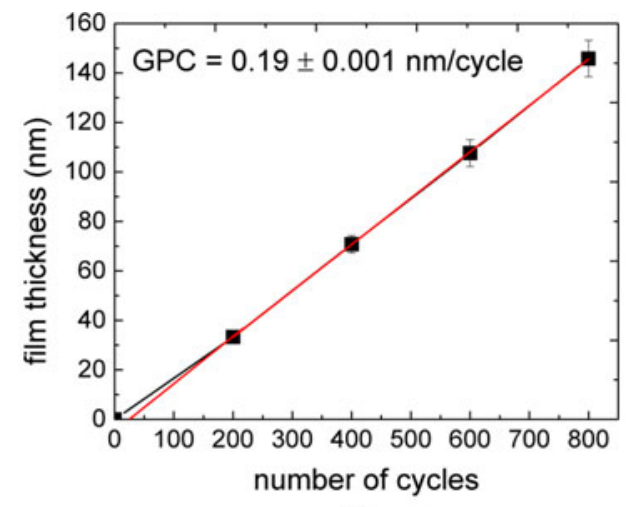

(a)

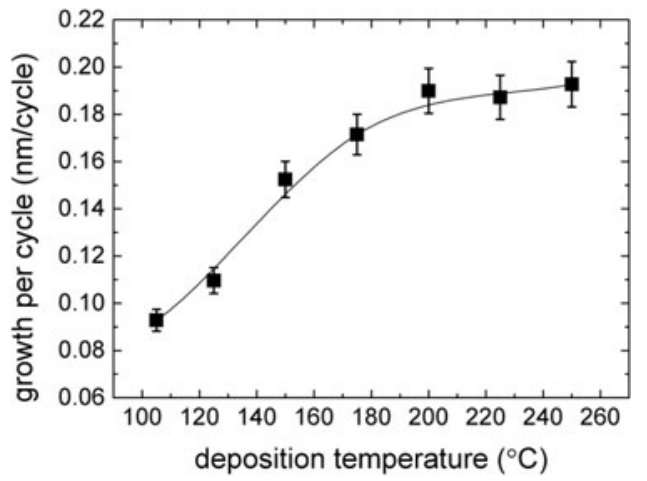

(b)

Fig. 2. (a) Film thickness as a function of the number of ALD cycles at a deposition temperature of $225^{\circ} \mathrm{C}$. GPC was determined from the slope of the curve determined from a linear fit of the measured data. (b) GPC as a function of deposition temperature for a DEZ partial pressure of 2 mbar, a water partial pressure of $65 \mathrm{mbar}$, and a pulse and purge time of $\sim 8 \mathrm{~ms}$ each.

precursor saturation regime [15]. Another point worthy to note is that some studies show a drop in the GPC of ALD deposited $i$-ZnO for substrate temperatures above $175^{\circ} \mathrm{C}$ [28], [29]. This is attributed to "precursor desorption" or specifically to the decrease in hydroxyls at the surface at higher temperatures. A detailed study by Nelson et al. showed that this desorption is influenced by the purge time, whereby longer purge cycles result in a decreased GPC [30]. In comparison, spatial ALD offers the advantage of very short purge durations, maintaining a high GPC even at higher deposition temperatures.

The spatially resolved thickness was measured for a polished $125 \mathrm{~mm} \times 125 \mathrm{~mm} c$-Si wafer and the thickness nonuniformity across the wafer was calculated using the following formula:

$$
\text { Nonuniformity }=\frac{d_{\max }-d_{\min }}{2 d_{\mathrm{avg}}} \times 100
$$

where $d_{\max }, d_{\min }$, and $d_{\text {avg }}$ are the maximum, minimum, and average thicknesses, respectively. With this formula the average nonuniformity value for a 100 -nm-thick $i$-ZnO film was $\sim 3.5 \%$. This value is $\sim 1 \%$ lower than the film nonuniformity values reported in the literature for $i$ - $\mathrm{ZnO}$ films deposited by temporal ALD [31]. By virtue of its self-saturating nature, ALD films should have high uniformity; nevertheless, nonuniformity in 


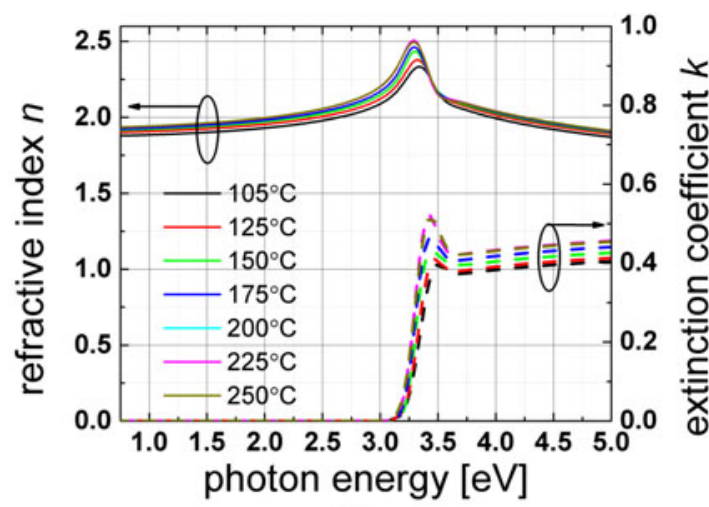

(a)

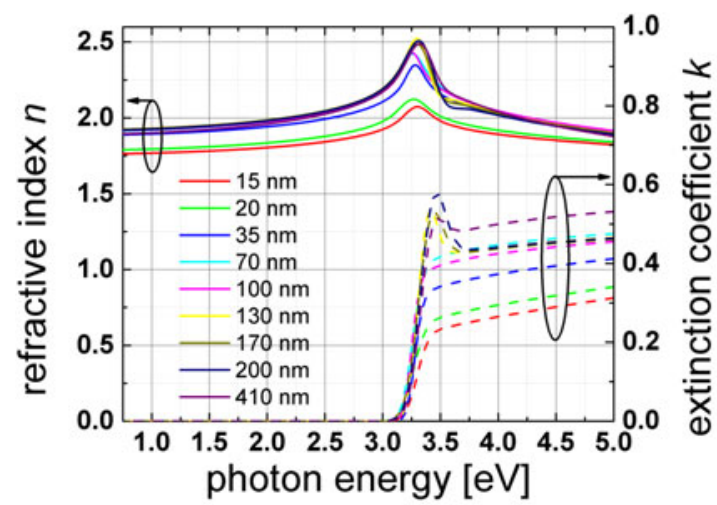

(b)

Fig. 3. Refractive index $(n)$ and extinction coefficient $(k)$ as a function of photon energy of $i$ - $\mathrm{ZnO}$ films deposited (a) at various temperatures and (b) with various thicknesses using a fixed deposition temperature of $230^{\circ} \mathrm{C}$.

the thickness of ALD films have been consistently observed, reported, and studied [31].

\section{B. Optical and Structural Properties}

Along with film thickness, the SE measurements were also used to extract $n$ and $k$ values of the $i$-ZnO films. Fig. 3 shows the $n$ and $k$ values as a function of photon energy for $i$-ZnO films (600 cycles) grown at different deposition temperatures. The film thicknesses vary with temperature due to the temperature dependence of the GPC. The measured dielectric functions are in close agreement with spectra reported in the literature for $i$-ZnO films [32], [33].

The refractive index of the deposited $i$ - $\mathrm{ZnO}$ films was found to be between 1.8 and 2.0 at a wavelength of $632 \mathrm{~nm}$, which is consistent with most reports in the literature [17]. The $n$ curves show a peak at the bandgap energy, as shown in Fig. 3(a). A shift in this $n$ peak is observed with increasing deposition temperature. This shift can be attributed to a change in the film quality with increasing deposition temperature. The absorption edge of the $k$ spectra was found to be at $\sim 3.3 \mathrm{eV}$, which corresponds closely to the $i-\mathrm{ZnO}$ bandgap. However, a distinct peak is observed at $\sim 3.4 \mathrm{eV}$, which is attributed to excitonic energies in wurtzite $\mathrm{ZnO}$ [34], [35]. The excitonic interaction of electrons and holes has a strong influence on the absorption spectrum, preventing the accurate determination of the bandgap value by

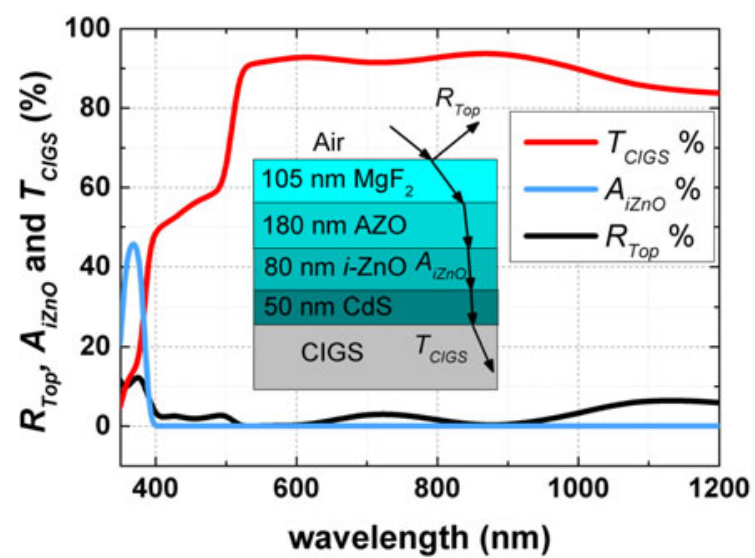

Fig. 4. Simulated reflection from the top surface $\left(R_{\text {Top }}\right)$, absorption in the $i$-ZnO layer $\left(A_{i \mathrm{ZnO}}\right)$, and transmission to the CIGS absorber $\left(T_{\mathrm{CIGS}}\right)$ for $i$-ZnO films applied as the window layer in a CIGS solar cell structure. (Inset) CIGS cell structure and interfaces used for the simulation.

extrapolation of the absorption edge. On the other hand, the presence of the excitonic peak indicates that the $i-\mathrm{ZnO}$ film is polycrystalline with possibly large crystal grains, indicating good film quality.

In Fig. 3(b), the shift in the $n$-spectra and the absence of the excitonic peak in the $k$-spectra for films with thickness of less than $50 \mathrm{~nm}$ could indicate that the thinner films are not completely developed in terms of crystallinity. However, it is also possible that the fit results for the very thin films are less reliable due to a relatively larger influence of the underlying $\mathrm{SiO}_{2}$ layer, which has a very low refractive index. However, the presence of the excitonic peak for higher thicknesses clearly indicates a high crystalline content in the $i$-ZnO films. Structural investigations using SEM presented below for different $i$ - $\mathrm{ZnO}$ thicknesses further support these observations.

The $n$ and $k$ values of $i$-ZnO deposited by spatial ALD obtained from SE measurements were further used to simulate the reflection, transmission, and absorption spectra for relevant interfaces in a CIGS solar cell structure with an $i$-ZnO layer between the $\mathrm{Al}$-doped $\mathrm{ZnO}$ front contact and the $\mathrm{CdS}$ buffer layer, as shown in the inset of Fig. 4. The simulated spectra are presented in Fig. 4 for an 80-nm-thick $i$-ZnO film deposited at $230{ }^{\circ} \mathrm{C}$. The $i-\mathrm{ZnO}$ film shows very low absorption $\left(A_{i \mathrm{ZnO}}\right)$ at wavelengths above $400 \mathrm{~nm}$. Hence, it gives high transmission to the CIGS absorber ( $T_{\text {CIGS }}$ ) of $>90 \%$ in the visible and NIR wavelength ranges, which makes the developed $i$ - $\mathrm{ZnO}$ films well suited for application as transparent window layers.

Fig. 5 shows SEM images of the top surface and cross section of a thick (400-nm) $i-\mathrm{ZnO}$ film on a $\mathrm{SiO}_{2}$ covered $c$-Si wafer. Columnar crystal grains with a grain size of the order of $50 \mathrm{~nm}$ can be seen. The columnar crystal structure was not observable for very thin $i$-ZnO films of $<50$-nm thickness. We believe that thin $i-\mathrm{ZnO}$ films do not have columnar grains, although it needs to be mentioned that clear SEM images were difficult to obtain for such samples due to their high resistivity, which resulted in electron charging. The large crystalline grains observed for the thicker $i$-ZnO films confirm their highly polycrystalline nature. 


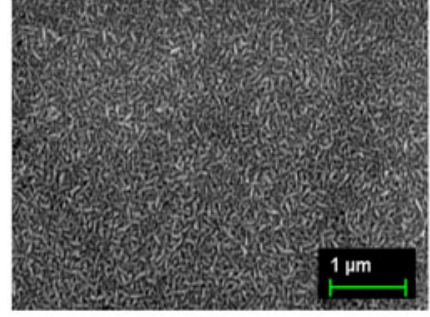

(a)

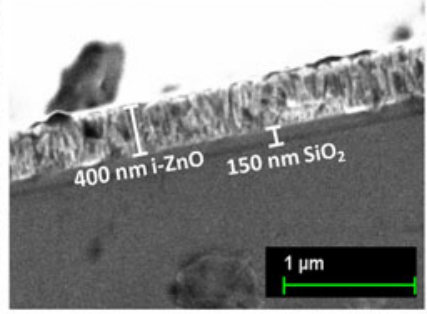

(b)
Fig. 5. (a) SEM micrograph (plan view) of a 400-nm-thick $i$-ZnO film deposited by spatial ALD on a $c-\mathrm{Si} / \mathrm{SiO}_{2}$ substrate. (b) SEM micrograph (cross section) of the sample of graph (a), showing a columnar grain structure.

TABLE I

PROPERTIES OF INTRINSIC ZnO FILMS DEPOSITED BY DIFFERENT TECHNIQUES

\begin{tabular}{|c|c|c|c|c|}
\hline $\begin{array}{l}\text { Deposition } \\
\text { technique }\end{array}$ & $\begin{array}{c}\text { Deposition } \\
\text { temperature }\left[{ }^{\circ} \mathrm{C}\right]\end{array}$ & $\begin{array}{l}\text { Resistivity } \\
{[\Omega \cdot \mathrm{cm}]}\end{array}$ & Comments & Ref. \\
\hline PECVD & 250 & $3 \times 10^{-3}$ & $\begin{array}{l}\text { UV exposure } \\
\sim 1 \mathrm{~min}\end{array}$ & {$[41]$} \\
\hline PLD & 200 & $4-7 \times 10^{-3}$ & & {$[42]$} \\
\hline Sputtering & $60-120$ & $\sim 4 \times 10^{-1}$ & & [43] \\
\hline MOCVD & 620 & 42.7 & & [44] \\
\hline Spray Pyrolysis & 180 & $10^{-3}$ & $\begin{array}{l}\text { Annealed in } \mathrm{N}_{2} \text { at } \\
400^{\circ} \mathrm{C}\end{array}$ & [45]-[46] \\
\hline Sol-Gel & 80 & 28.2 & $\begin{array}{l}\text { Annealed in air at } \\
500-600{ }^{\circ} \mathrm{C}\end{array}$ & [47] \\
\hline Temporal ALD & $200-220$ & $\sim 1 \times 10^{-3}$ & $\begin{array}{l}\text { Exposure } \sim 1 \mathrm{~s}, \\
\text { Purge } \sim 10 \mathrm{~s}\end{array}$ & [5] \\
\hline $\begin{array}{l}\text { Spatial } \\
\text { ALD-prototype }\end{array}$ & $75-250$ & $4 \times 10^{-3}$ & Exposure $\sim 30 \mathrm{~ms}$ & [17] \\
\hline This work & $200-225$ & $\sim 100-200$ & $\begin{array}{l}\text { Purge } \sim 0.3 \mathrm{~s} \\
\text { Exposure } \sim 8 \mathrm{~ms} \\
\text { Purge } \sim 8 \mathrm{~ms}\end{array}$ & \\
\hline
\end{tabular}

*PECVD = Plasma-enhanced chemical vapor deposition, PLD = Pulsed laser deposition, MOCVD $=$ Metal-organic chemical vapor deposition, ALD = Atomic layer deposition

This also corresponds well with the observations from the $n$ and $k$ spectra in Fig. 3.

\section{Electrical Properties}

$i-\mathrm{ZnO}$ films are intrinsically n-type and are frequently reported to be highly conductive, with resistivity values as low as $10^{-3} \Omega \cdot \mathrm{cm}$ being reported for as-grown $i$ - $\mathrm{ZnO}$ without any additional doping, as summarized in Table I. In contrast, the $i$-ZnO films deposited in this study all showed very high sheet resistances of the order of $10^{7}-10^{8} \Omega / \mathrm{sq}$ for $100-\mathrm{nm}$ films, corresponding to a film resistivity in the range of $100-200 \Omega \cdot \mathrm{cm}$; see Fig. 6. Nelson et al. [30] recently showed that the resistivity of $i$ - $\mathrm{ZnO}$ films exponentially increases with decreasing purge time after the DEZ exposure. They reported sheet resistance values of $\sim 10^{5} \Omega / \mathrm{sq}$ for a 100 -nm-thick $i$-ZnO film deposited with pulse and purge times of $80 \mathrm{~ms}$. Specifically, their study showed that for a fixed exposure time ( $2 \mathrm{~s})$, the DEZ purge time influences the resistivity much more than the $\mathrm{H}_{2} \mathrm{O}$ purge time.

Here, it is worthy to note that the exposure and purge cycles for this spatial ALD are asymmetric, in contrast with conventional temporal ALD. The details of the spatial ALD process used in this study are shown in Fig. 7. Unlike in temporal ALD

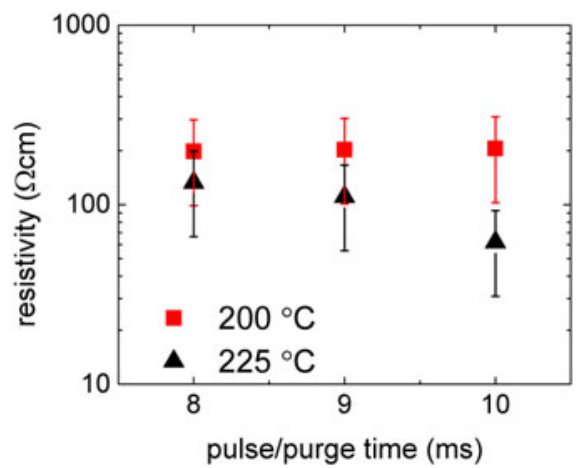

Fig. 6. Film resistivity as a function of pulse and purge duration (ms) for 100 -nm-thick $\mathrm{ZnO}$ films deposited at 200 and $225^{\circ} \mathrm{C}$.

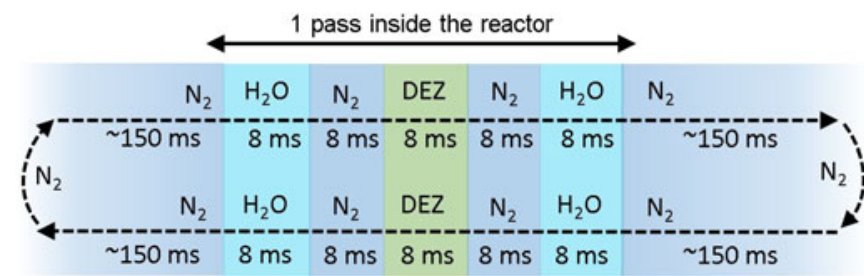

Fig. 7. Schematic highlighting the DEZ and $\mathrm{H}_{2} \mathrm{O}$ pulse and purge durations experienced by the substrate during one back-and-forth motion for the spatial ALD technique used in this study.

(where a sample is exposed to consecutive $\mathrm{H}_{2} \mathrm{O}$-purge-DEZpurge- $\mathrm{H}_{2} \mathrm{O}$-purge-DEZ cycles), in spatial ALD, the sample experiences two $\mathrm{H}_{2} \mathrm{O}$ exposures after each DEZ exposure. The DEZ/ $\mathrm{H}_{2} \mathrm{O}$ exposure times (for a constant wafer speed) are each $\sim 8 \mathrm{~ms}$. The purge time between the $\mathrm{H}_{2} \mathrm{O}$ and the DEZ exposures is also $\sim 8 \mathrm{~ms}$ during each wafer pass. Upon completion of one pass, the wafer is pushed back by a pulse of $\mathrm{N}_{2}$ (as seen in Fig. 1), and this results in a longer $\mathrm{N}_{2}$ purge followed by another $\mathrm{H}_{2} \mathrm{O}$ exposure.

As mentioned earlier, Nelson et al. also showed that longer purge times result in lower growth rates, most likely due to desorption of the hydroxyl $(\mathrm{OH})$ groups. If this was the case, the 300-ms-long purge in our system would result in higher desorption of $(\mathrm{OH})$ groups from the surface. However, the subsequent second $\mathrm{H}_{2} \mathrm{O}$ exposure refreshes the surface with $(\mathrm{OH})$ groups followed by only a short $\sim 8 \mathrm{~ms}_{2}$ purge that prevents any further desorption.

Keeping this in mind, the high resistivity of the $i-\mathrm{ZnO}$ films deposited in this study is easily explained by the results of Nelson et al. The DEZ pulse/purge time in our spatial ALD system was $\sim 8 \mathrm{~ms}$, much shorter than the $80 \mathrm{~ms}$ used in [30]. This also explains the high resistivities obtained by spatial ALD compared with temporal ALD where the exposure and purge durations are of the order of $\sim 1$ and $\sim 10 \mathrm{~s}$, respectively. On the other hand, Illiberi et al. reported a low resistivity of $4 \times 10^{-3} \Omega$ . $\mathrm{cm}$ for $i-\mathrm{ZnO}$ films that were deposited by spatial ALD. This low resistivity value can be explained by noting that in their spatial ALD setup the DEZ/ $\mathrm{H}_{2} \mathrm{O}$ exposure time is $\sim 30 \mathrm{~ms}$ and the purge time is $\sim 0.3 \mathrm{~s}$, both significantly longer than the time durations used in this study. From an industrial point of view, 


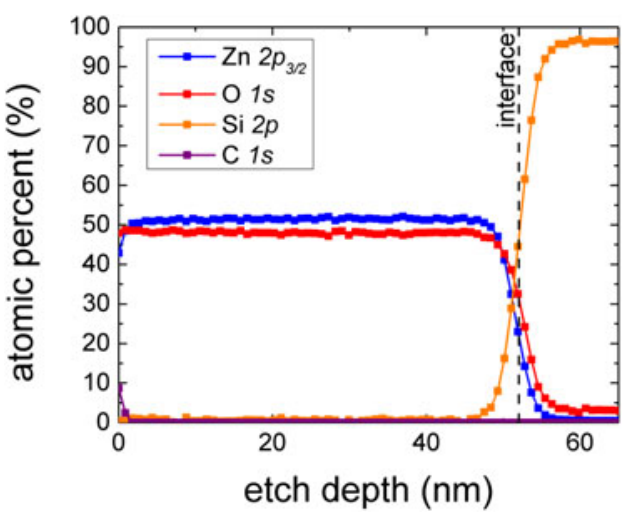

Fig. 8. XPS depth profile of a $50-\mathrm{nm} i$-ZnO film deposited at $225^{\circ} \mathrm{C}$ with a DEZ partial pressure of $2 \mathrm{mbar}$, a water partial pressure of $65 \mathrm{mbar}$, and pulse and purge durations of $\sim 8 \mathrm{~ms}$ each.

it should also be noted that longer pulse/purge durations would result in lower deposition rates; hence, shorter pulse/purge durations are more desirable for high volume manufacturing.

The additional carriers in less resistive $i$ - $\mathrm{ZnO}$ films are often associated with defects due to oxygen vacancies, while higher oxygen content and oxygen interstitials are associated with high resistivity [4], [5], [29], [36], [37]. The observations in this study fit this line of thinking very well. With shorter exposure/purge times, it is expected that the $\mathrm{O}$ atoms have a lower probability to desorb from the surface, resulting in fewer oxygen vacancies and hence a lower defect density, which corresponds to a higher resistivity. This is further supported by the lower resistivity obtained for films deposited at $225^{\circ} \mathrm{C}$, as compared with those deposited at $200{ }^{\circ} \mathrm{C}$. It is expected that higher temperature also results in higher densities of vacancies and defects.

\section{Material Properties}

In Fig. 8, the atomic percentage (at\%) of oxygen, zinc, silicon, and carbon as obtained from the XPS depth profiles are presented for an $i-\mathrm{ZnO}$ film deposited at $225^{\circ} \mathrm{C}$. First, no carbon contamination was detected in the bulk of the film. Second, the relative at $\%$ of $\mathrm{O}$ is seen to be comparable to that of $\mathrm{Zn}$ indicating that the $i-\mathrm{ZnO}$ films are nearly stoichiometric. This corresponds well with earlier reports for $\mathrm{ZnO}$ films prepared by ALD [38] and indicates that there is no significant $\mathrm{O} / \mathrm{OH}$ deficiency in the films due to the short pulse and purge durations.

The variation in crystal orientation with changing deposition temperature of $i$ - $\mathrm{ZnO}$ films was measured with XRD; see Fig. 9. The predominant grain orientation of the films changed from $\left(\begin{array}{lll}0 & 0 & 2\end{array}\right)$ at low deposition temperature $\left(\begin{array}{lll}10{ }^{\circ} \mathrm{C}\end{array}\right)$ to $\left(\begin{array}{lll}1 & 0 & 0\end{array}\right)$ for high deposition temperature $\left(250^{\circ} \mathrm{C}\right)$. Most reports in the literature on $i$-ZnO deposited by temporal ALD show a predominant grain orientation of ( $\left.\begin{array}{lll}0 & 0 & 2\end{array}\right)$ [39], [40]. Nelson et al. also found that with shorter exposure/purge times, the $\left(\begin{array}{lll}1 & 0 & 0\end{array}\right)$ and (1 $\left.\begin{array}{lll}1 & 1\end{array}\right)$ peaks seemed to dominate [30], whereas at longer exposure/purge durations, the $\left(\begin{array}{lll}0 & 0\end{array}\right)$ orientation dominates. This is consistent with the dominance of the $\left(\begin{array}{lll}1 & 0 & 0\end{array}\right)$ peak over the $\left(\begin{array}{lll}0 & 0 & 2\end{array}\right)$ peak in the $i$ - $\mathrm{ZnO}$ films deposited in this study. The preferred $\left(\begin{array}{lll}1 & 0 & 0\end{array}\right)$ orientation is consistent with earlier results for

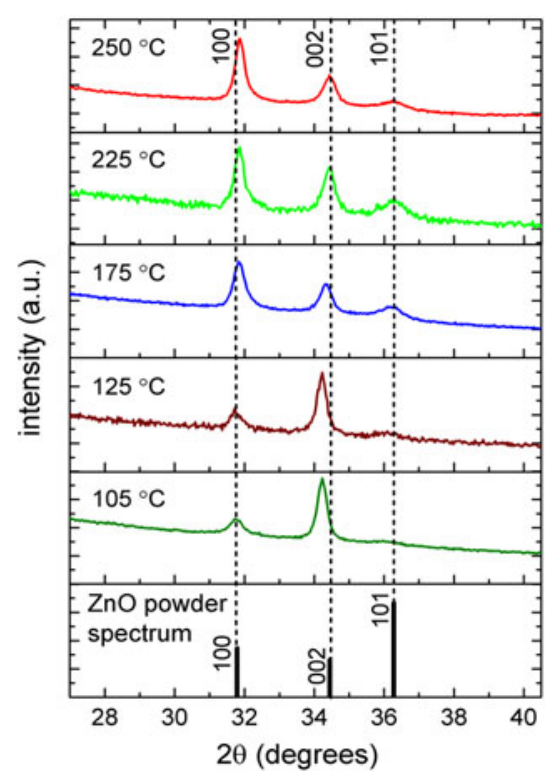

Fig. 9. XRD $2 \theta$ scan of $i$ - $\mathrm{ZnO}$ films grown at different deposition temperatures, showing a change in the preferential crystal orientation. The $i$ - $\mathrm{ZnO}$ powder spectrum has been included for reference.

$i$ - $\mathrm{ZnO}$ deposited by spatial ALD [17]. It was proposed that the longer exposure/purge times increase the ability of the precursor molecule to find low-energy sites on the surface.

\section{CONCLUSION}

Using spatial ALD, the deposition of intrinsic $\mathrm{ZnO}$ films was scaled up resulting in a high deposition rate of $\sim 35 \mathrm{~nm} / \mathrm{min}$ on large-area $(125 \mathrm{~mm} \times 125 \mathrm{~mm}) c$-Si substrates. The $i$ - $\mathrm{ZnO}$ films have a high resistivity $(\sim 100 \Omega \cdot \mathrm{cm})$ and a refractive index that results in a high transparency $(>90 \%)$ in the visible range. The high resistivities of the $i$-ZnO films deposited in this study are attributed to the short precursor exposure and purge times of the spatial ALD technique, as compared with other deposition techniques. XPS results showed that the $i$-ZnO films were nearly stoichiometric. The preferential crystallographic orientation of the $i$ - ZnO films was found to be $\left(\begin{array}{lll}1 & 0 & 0\end{array}\right)$ at higher deposition temperatures, rather than $\left(\begin{array}{lll}0 & 0 & 2\end{array}\right)$ as reported for conventional temporal ALD $\mathrm{ZnO}$ films. This is also attributed to the short exposure/purge times. These properties make these $i$ - $\mathrm{ZnO}$ films ideal for application as the window layer between the CdS buffer and the conductive front contact in CIGS solar cells in order to reduce the influence of absorber layer defects from affecting the cell performance. However, one should take into account that $\mathrm{ZnO}$ would grow differently on $\mathrm{CdS}$ as compared to $c-\mathrm{Si}$, resulting in potentially varying material properties. For applications of $\mathrm{ZnO}$ as a transparent conductive oxide in CIGS and silicon heterojunction solar cells, lower resistivities are desired and can be achieved by impurity doping, e.g., Al-, B-, Ga-, or In-doped $\mathrm{ZnO}$. This preliminary study on $i-\mathrm{ZnO}$ paves the way for its application in existing and new PV technologies, while the advantages of the spatial ALD technique described in this study make it an attractive option for the PV industry. 


\section{ACKNOWLEDGMENT}

The authors would like to thank P. Sutmuller and R. van Zuilekom for their significant support and assistance with sample preparation, M. Tang for help with obtaining SEM images, and W.-L. Xu and Y. Xia for data on $n$ and $k$ values of AZO and CdS.

\section{REFERENCES}

[1] V. Coleman and C. Jagadish, "Basic properties and applications of ZnO," in Zinc Oxide Bulk, Thin Films and Nanostructures: Processing, Properties, and Applications. New York, NY, USA: Elsevier, 2006, pp. 1-20.

[2] C. Jagadish and S. J. Pearton, Zinc Oxide Bulk, Thin Films and Nanostructures: Processing, Properties, and Applications. New York, NY, USA: Elsevier, 2011.

[3] H. Nanto, T. Minami, and S. Takata, "Zinc oxide thin film ammonia gas sensors with high sensitivity and excellent selectivity," J. Appl. Phys., vol. 60 , pp. $482-484,1986$.

[4] K. Ellmer, A. Klein, and B. Rech, Transparent Conductive Zinc Oxide: Basics and Applications in Thin Film Solar Cells, vol. 104. New York, NY, USA: Springer, 2007.

[5] T. Tynell and M. Karppinen, "Atomic layer deposition of $\mathrm{ZnO}$ : A review," Semicond. Sci. Technol., vol. 29, p. 043001, 2014.

[6] I. Repins, M. A. Contreras, B. Egaas, C. DeHart, J. Scharf, C. L. Perkins, B. To, and R. Noufi, " $19.9 \%$ efficient $\mathrm{ZnO} / \mathrm{CdS} / \mathrm{CuInGaSe} 2$ solar cell with 81.2\% fill factor," Prog. Photovoltaics, Res. Appl., vol. 16, pp. 235-239, 2008.

[7] P. Jackson, D. Hariskos, E. Lotter, S. Paetel, R. Wuerz, R. Menner, W. Wischmann, and M. Powalla, "New world record efficiency for $\mathrm{Cu}$ (In, Ga) $\mathrm{Se}_{2}$ thin film solar cells beyond 20\%," Prog. Photovoltaics, Res. Appl., vol. 19, pp. 894-897, 2011.

[8] S. De Wolf, A. Descoeudres, Z. C. Holman, and C. Ballif, "High-efficiency silicon heterojunction solar cells: A review," Green, vol. 2, pp. 7-24, 2012.

[9] S. Ishizuka, K. Sakurai, A. Yamada, K. Matsubara, P. Fons, K. Iwata, S. Nakamura, Y. Kimura, T. Baba, H. Nakanishi, T. Kojima, and S. Nikia, "Fabrication of wide-gap $\mathrm{Cu}\left(\mathrm{In}_{1-x} \mathrm{Ga}_{x}\right) \mathrm{Se}_{2}$ thin film solar cells: A study on the correlation of cell performance with highly resistive i-ZnO layer thickness," Solar Energy Mater. Solar Cells, vol. 87, pp. 541-548, 2005.

[10] U. Rau and M. Schmidt, "Electronic properties of $\mathrm{ZnO} / \mathrm{CdS} / \mathrm{Cu}$ (In, Ga) $\mathrm{Se}_{2}$ solar cells-Aspects of heterojunction formation," Thin Solid Films, vol. 387, pp. 141-146, 2001.

[11] P. Grabitz, U. Rau, and J. Werner, "Modeling of spatially inhomogeneous solar cells by a multi diode approach," Phys. Status Solidi (a), vol. 202, pp. 2920-2927, 2005.

[12] P. Grabitz, U. Rau, and J. Werner, "Electronic inhomogeneities and the role of the intrinsic $\mathrm{ZnO}$ layer in $\mathrm{Cu}(\mathrm{In}, \mathrm{Ga}) \mathrm{Se}_{2}$ thin film solar cells," in Proc. 20th Eur. Photovoltaic Sol. Energy Conf., 2005, pp. 1771-1774.

[13] S. Niki, M. Contreras, I. Repins, M. Powalla, K. Kushiya, S. Ishizuka, and K. Matsubara, "CIGS absorbers and processes," Prog. Photovoltaics, Res. Appl., vol. 18, pp. 453-466, 2010.

[14] T. Nakada and M. Mizutani, "18\% efficiency Cd-free $\mathrm{Cu}$ (In, Ga) $\mathrm{Se}_{2}$ thin-film solar cells fabricated using chemical bath deposition (CBD)ZnS buffer layers," Jpn. J. Appl. Phys., vol. 41, p. L165, 2002.

[15] B. Macco, D. Deligiannis, S. Smit, R. van Swaaij, M. Zeman, and W. Kessels, "Influence of transparent conductive oxides on passivation of a-Si: H/c-Si heterojunctions as studied by atomic layer deposited Aldoped ZnO," Semicond. Sci. Technol., vol. 29, p. 122001, 2014.

[16] P. Poodt, A. Lankhorst, F. Roozeboom, K. Spee, D. Maas, and A. Vermeer, "High-speed spatial atomic-layer deposition of aluminum oxide layers for solar cell passivation," Adv Mater, vol. 22, pp. 3564-3567, 2010.

[17] A. Illiberi, F. Roozeboom, and P. Poodt, "Spatial atomic layer deposition of zinc oxide thin films," ACS Appl. Mater. Interfaces, vol. 4, pp. 268-272, 2011.

[18] N. Nandakumar, B. Dielissen, D. Garcia-Alonso, Z. Liu, W. M. Kessels, R. Gortzen, A. G. Aberle, and B. Hoex, "Spatial atomic layer deposition of intrinsic zinc oxide films for applications in the photovoltaic industry," in Proc. 6th WCPEC Conf., 2014, pp. 577-578.

[19] E. Guziewicz, I. Kowalik, M. Godlewski, K. Kopalko, V. Osinniy, A. Wójcik, S. Yatsunenko, E. Łusakowska, W. Paszkowicz, and M. Guziewicz, "Extremely low temperature growth of $\mathrm{ZnO}$ by atomic layer deposition," J. Appl. Phys., vol. 103, p. 033515, 2008.

[20] W. Kern, "Cleaning solutions based on hydrogen peroxide for use in silicon semiconductor technology," RCA Rev., vol. 31, pp. 187-206, 1970.
[21] B. D. Johs, J. A. Woollam, C. M. Herzinger, J. N. Hilfiker, R. A. Synowicki, and C. L. Bungay, "Overview of variable-angle spectroscopic ellipsometry (VASE): II. Advanced applications," in Proc. Soc. Photo-Opt. Instrum. Eng. (SPIE) Conf. Ser., 1999, pp. 29-58.

[22] J. M. Siqueiros, R. Machorro, and L. E. Regalado, "Determination of the optical constants of $\mathrm{MgF}_{2}$ and $\mathrm{ZnS}$ from spectrophotometric measurements and the classical oscillator method," Appl. Opt., vol. 27, pp. 2549-2553, 1988.

[23] L. Ward, "Cadmium Sulphide (CdS)," in Handbook of Optical Constants of Solids, E. D. Palik, Ed. Boston, MA, USA: Academic, 1998, pp. 579-595.

[24] P. D. Paulson, R. W. Birkmire, and W. N. Shafarman, "Optical characterization of $\mathrm{CuIn}_{1-x} \mathrm{Ga}_{x} \mathrm{Se}_{2}$ alloy thin films by spectroscopic ellipsometry," J. Appl. Phys., vol. 94, pp. 879-888, 2003.

[25] D. Garcia-Alonso, S. E. Potts, C. A. van Helvoirt, M. A. Verheijen, and W. M. Kessels, "Atomic layer deposition of B-doped $\mathrm{ZnO}$ using triisopropyl borate as the boron precursor and comparison with Al-doped $\mathrm{ZnO}$," J. Mater. Chem. C, vol. 3, pp. 3095-3107, 2015.

[26] J. Ferguson, A. Weimer, and S. George, "Surface chemistry and infrared absorbance changes during $\mathrm{ZnO}$ atomic layer deposition on $\mathrm{ZrO}_{2}$ and $\mathrm{BaTiO}_{3}$ particles," J. Vacuum Sci. Technol. A: Vacuum, Surfaces, Films, vol. 23, pp. 118-125, 2005.

[27] E. B. Yousfi, J. Fouache, and D. Lincot, "Study of atomic layer epitaxy of zinc oxide by in-situ quartz crystal microgravimetry," Appl. Surface Sci., vol. 153 , pp. 223-234, 2000.

[28] S. Lim, S. Kwon, and H. Kim, "ZnO thin films prepared by atomic layer deposition and RF sputtering as an active layer for thin film transistor," Thin Solid Films, vol. 516, pp. 1523-1528, 2008.

[29] D. Kim, H. Kang, J.-M. Kim, and H. Kim, "The properties of plasmaenhanced atomic layer deposition (ALD) $\mathrm{ZnO}$ thin films and comparison with thermal ALD," Appl. Surface Sci., vol. 257, pp. 3776-3779, 2011.

[30] S. F. Nelson, D. H. Levy, L. W. Tutt, and M. Burberry, "Cycle time effects on growth and transistor characteristics of spatial atomic layer deposition of zinc oxide," J. Vacuum Sci. Technol. A, vol. 30, p. 01A154, 2012.

[31] K. E. Elers, T. Blomberg, M. Peussa, B. Aitchison, S. Haukka, and S. Marcus, "Film uniformity in atomic layer deposition," Chem. Vapor Deposition, vol. 12, pp. 13-24, 2006.

[32] H. Fujiwara and M. Kondo, "Effects of carrier concentration on the dielectric function of $\mathrm{ZnO}: \mathrm{Ga}$ and $\mathrm{In}_{2} \mathrm{O}_{3}$ :Sn studied by spectroscopic ellipsometry: Analysis of free-carrier and band-edge absorption," Phys. Rev. $B$, vol. 71, p. 075109, 2005.

[33] K. Postava, H. Sueki, M. Aoyama, T. Yamaguchi, C. Ino, Y. Igasaki, and M. Horie, "Spectroscopic ellipsometry of epitaxial $\mathrm{ZnO}$ layer on sapphire substrate," J. Appl. Phys., vol. 87, pp. 7820-7824, 2000.

[34] J. Muth, R. Kolbas, A. Sharma, S. Oktyabrsky, and J. Narayan, "Excitonic structure and absorption coefficient measurements of $\mathrm{ZnO}$ single crystal epitaxial films deposited by pulsed laser deposition," J. Appl. Phys., vol. 85, pp. 7884-7887, 1999.

[35] G. Jellison and L. Boatner, "Optical functions of uniaxial $\mathrm{ZnO}$ determined by generalized ellipsometry," Phys. Rev. B, vol. 58, p. 3586, 1998.

[36] A. Pimentel, E. Fortunato, A. Gonçalves, A. Marques, H. Aguas, L. Pereira, I. Ferreira, and R. Martins, "Polycrystalline intrinsic zinc oxide to be used in transparent electronic devices," Thin Solid Films, vol. 487, pp. 212-215, 2005

[37] W. Jeong, S. Kim, and G. Park, "Preparation and characteristic of $\mathrm{ZnO}$ thin film with high and low resistivity for an application of solar cell," Thin Solid Films, vol. 506, pp. 180-183, 2006.

[38] Y. Wu, P. Hermkens, B. Van de Loo, H. Knoops, S. Potts, M. Verheijen, F. Roozeboom, and W. M. M. Kessels, "Electrical transport and Al doping efficiency in nanoscale $\mathrm{ZnO}$ films prepared by atomic layer deposition," J. Appl. Phys., vol. 114, p. 024308, 2013.

[39] W. Maeng and J.-S. Park, "Growth characteristics and film properties of gallium doped zinc oxide prepared by atomic layer deposition," J. Electroceramics, vol. 31, pp. 338-344, 2013.

[40] D. H. Levy, S. F. Nelson, and D. Freeman, "Oxide electronics by spatial atomic layer deposition," J. Display Technol., vol. 5, pp. 484-494, 2009.

[41] A. Illiberi, F. Grob, C. Frijters, P. Poodt, R. Ramachandra, H. Winands, M. Simor, and P. J. Bolt, "High rate $(\sim 7 \mathrm{~nm} / \mathrm{s})$, atmospheric pressure deposition of $\mathrm{ZnO}$ front electrode for $\mathrm{Cu}$ (In, Ga) Se2 thin-film solar cells with efficiency beyond 15\%," Prog. Photovoltaics, Res. Appl., vol. 21, pp. 1559-1566, 2013.

[42] J.-L. Zhao, X.-M. Li, J.-M. Bian, W.-D. Yu, and X.-D. Gao, "Structural, optical and electrical properties of $\mathrm{ZnO}$ films grown by pulsed laser deposition (PLD)," J. Crystal Growth, vol. 276, pp. 507-512, 2005. 
[43] R. Cebulla, R. Wendt, and K. Ellmer, "Al-doped zinc oxide films deposited by simultaneous RF and dc excitation of a magnetron plasma: relationships between plasma parameters and structural and electrical film properties," J. Appl. Phys., vol. 83, pp. 1087-1095, 1998.

[44] Y. Ma, G. Du, S. Yang, Z. Li, B. Zhao, X. Yang, T. P. Yang, Y. T. Zhang, and D. L. Liu, "Control of conductivity type in undoped $\mathrm{ZnO}$ thin films grown by metalorganic vapor phase epitaxy," J. Appl. Phys., vol. 95, pp. 6268-6272, 2004.

[45] F. Paraguay D, W. Estrada L, D. Acosta N, E. Andrade, and M. MikiYoshida, "Growth, structure and optical characterization of high quality $\mathrm{ZnO}$ thin films obtained by spray pyrolysis," Thin Solid Films, vol. 350, pp. 192-202, 1999.

[46] S. Studenikin, N. Golego, and M. Cocivera, "Optical and electrical properties of undoped $\mathrm{ZnO}$ films grown by spray pyrolysis of zinc nitrate solution," J. Appl. Phys., vol. 83, pp. 2104-2111, 1998.

[47] Y. Natsume and H. Sakata, "Zinc oxide films prepared by sol-gel spincoating," Thin Solid Films, vol. 372, pp. 30-36, 2000.

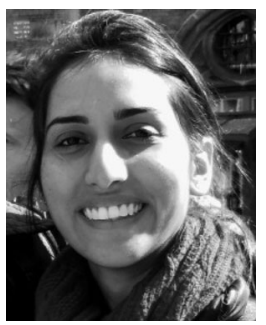

Naomi Nandakumar received the B.Sc. degree in physics from Osmania University, Hyderabad, India, in 2010 and the M.Sc. degree in applied physics from the National University of Singapore (NUS), Singapore, in 2012. She is currently working toward the Ph.D. degree with the Solar Energy Research Institute of Singapore (SERIS) at NUS.

Her research focuses on the development and characterization of thin films deposited by atomic layer deposition for photovoltaic applications.

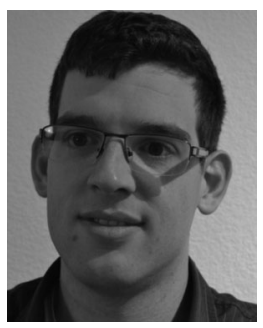

Bas Dielissen received the B.Sc. and M.Sc. degrees in applied physics from the Eindhoven University of Technology, Eindhoven, The Netherlands, in 2009 and 2011, respectively.

After that, he continued his work with Eindhoven University of Technology, for half a year. In 2012, he joined SoLayTec, Eindhoven, as a Process Engineer, working on the development and optimization of the current and new atomic layer deposition processes, as well as the implementation of these processes in the fabrication of solar cells.

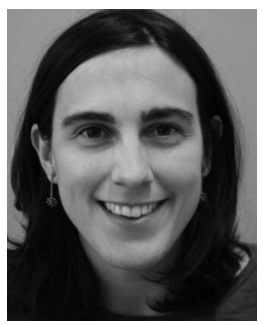

Diana Garcia-Alonso received the Industrial Engineering degree from the University of Málaga, Málaga, Spain, in 2004 and the Ph.D. degree from Dublin City University, Dublin, Ireland, in 2009.

She joined the Plasma and Materials Processing Group with the Eindhoven University of Technology, Eindhoven, The Netherlands, as a Postdoctoral Researcher in October 2010. Her research interests include atomic layer deposition of different materials for photovoltaics.

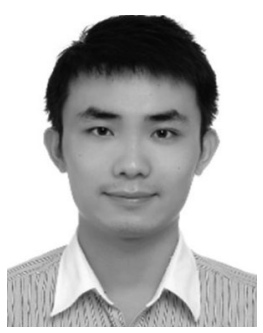

Zhe Liu received the B.Eng. degree in electrical engineering from National University of Singapore, Singapore, in 2012. He is currently working toward the Ph.D. degree with the Department of Electrical and Computer Engineering and the Solar Energy Research Institute of Singapore, Singapore.

His research interest includes simulations and characterizations of silicon solar cells.

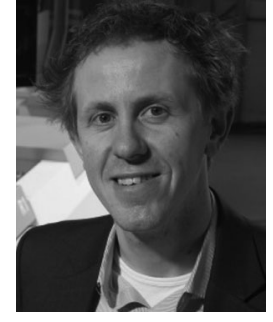

Roger Görtzen received the Bachelor's degree from the Hogeschool van Utrecht, Utrecht, The Netherlands, in 2001. His final thesis was about micropositioning of electronic components in the field of microsystems.

From 2001 to 2010 he was with TNO Science and Industry (Dutch research organization), working in the field of backend and frontend semiconductor industry. He began as a Precision Engineer, and later, he developed his skills as Business Developer for new technologies: One project lead to the spin off of the spatial atomic layer deposition (ALD) technology for Photovoltaics. He has written several papers, holds four patents, and has received two awards. Since 2010, he has been the co-Founder and Director of marketing and sales for SoLayTec, Eindhoven, The Netherlands. SoLayTec ALD machines are designed for mass production in the solar market. In the field of solar cell ALD equipment, SoLayTec has a leading position.

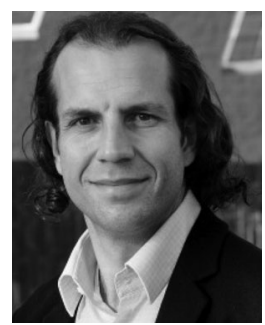

Wilhelmus M. M. (Erwin) Kessels received the M.Sc. and Ph.D. degrees (with highest honors) in applied physics from the Eindhoven University of Technology (TU/e), Eindhoven, The Netherlands, in 1996 and 2000, respectively.

$\mathrm{He}$ is currently a full Professor with TU/e, where he is also the Scientific Director of the NanoLab@TU/e clean room facilities. His research interests include the field of synthesis of ultrathin films and nanostructures using methods such as (plasma-enhanced) chemical vapor deposition and atomic layer deposition (ALD) for a wide variety of applications, mostly within nanoelectronics and photovoltaics. As such, he has pioneered the application of ALD and $\mathrm{Al}_{2} \mathrm{O}_{3}$ films for the surface passivation of crystalline silicon solar cells. Currently, his group is exploring the use of ALD-prepared films and nanoparticles in many more types of solar cells.

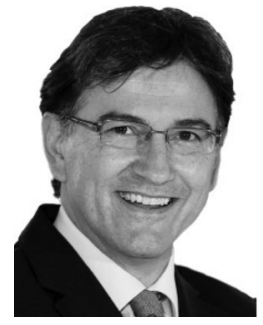

Armin G. Aberle received the Physicist degree from the University of Freiburg, Freiburg, Germany, in 1988; the Ph.D. degree in physics from the University of Freiburg in 1992; and the Dr. rer. nat. habil. degree in physics from the University of Hannover, Hannover, Germany, in 1999.

$\mathrm{He}$ is currently the Chief Executive Officer of the Solar Energy Research Institute of Singapore (SERIS), National University of Singapore (NUS), Singapore. His research focus is on industrially relevant photovoltaic materials, devices, and modules. He has published extensively ( $>350$ papers), and his work has a high impact (>6000 citations). He is on the Editorial Board of several scientific-technical journals. In the 1990s, he established the Silicon Photovoltaics (PV) Department at ISFH, Hamelin, Germany. He then worked for ten years in Australia as a Professor of photovoltaics with the University of New South Wales, Sydney, Australia. In 2008, he joined NUS to establish SERIS, with particular responsibility for the creation of a Silicon PV Department.

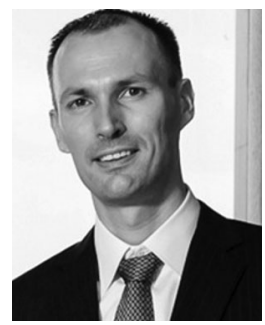

Bram Hoex received the M.Sc. and Ph.D. degrees in applied physics from the Eindhoven University of Technology, Eindhoven, The Netherlands, in 2003 and 2008, respectively.

He is currently a Senior Lecturer with the School of Photovoltaic and Renewable Energy Engineering, University of New South Wales, Sydney, Australia. Previously, he was Director and Group Leader with the Solar Energy Research Institute of Singapore, $\mathrm{Na}$ tional University of Singapore. His research interests include advanced fabrication and characterization of high-efficiency silicon wafer solar cells 